\title{
ANFIS-sliding mode control of a DFIG supplied by a two-level SVPWM technique for wind energy conversion system
}

\author{
Habib Benbouhenni
}

Department of Electrical Engineering, National Polytechnique School of Oran Maurice Audin, Algeria

\begin{tabular}{l} 
Article Info \\
\hline Article history: \\
Received May 29, 2019 \\
Revised Sep 18, 2019 \\
Accepted Feb 19, 2020 \\
\hline
\end{tabular}

Keywords:

ANFIS-SMC

DFIG

SMC

SVM

THD

\begin{abstract}
A modified adaptive neuro-fuzzy inference system sliding mode control (ANFIS-SMC) by using two-level space vector pulse width modulation (SVPWM) for doubly fed induction generator (DFIG) is proposed in this article. ANFIS-SMC with SVPWM strategy improves the basic SMC performances, which features low stator active and reactive power and also minimize the total distortion harmonic (THD) of stator current. The computer simulation results, in Matlab, demonstrate the effectiveness of the proposed control strategy which improves the performance of the DFIG.
\end{abstract}

\section{Corresponding Author:}

Habib Benbouhenni,

Department of Electrical Engineering,

National Polytechnique School of Oran Maurice Audin,

Oran, Algeria.

Email: habib0264@gmail.com

\section{NOMENCLATURE}

$\begin{array}{ll}\text { WTS } & \text { Wind turbine system } \\ \text { DFIG } & \text { Doubly fed induction generator } \\ \text { WECS } & \text { Wind energy conversion systems } \\ \text { ANFIS } & \text { Adaptive neuro-fuzzy inference system } \\ \text { SMC } & \text { Sliding mode control } \\ \text { THD } & \text { Total distortion harmonic } \\ \text { SVPWM } & \text { Space vector pulse width modulation } \\ \text { DTC } & \text { Direct vector control } \\ \text { DPC } & \text { Direct power control } \\ \text { SOSMC } & \text { Second order sliding mode controller } \\ \text { ANN } & \text { Artificial neural network } \\ \text { FL } & \text { Fuzzy logic } \\ L_{r}, L_{s} & \text { Stator and rotor self-inductances } \\ L_{m} & \text { Mutual inductance } \\ R_{r}, R_{s} & \text { Stator and rotor resistances } \\ \psi_{r}, \psi_{s} & \text { Rotor and Stator flux vectors } \\ I_{s}, I_{r} & \text { Rotor and stator current vectors } \\ V_{s}, V_{r} & \text { Rotor and stator voltage vectors } \\ \mathrm{P}_{\mathrm{s}}, \mathrm{Q}_{\mathrm{s}} & \text { Active and reactive powers. } \\ \mathrm{r}, \mathrm{s} & \text { Rotor, stator } \\ d, q & \text { Synchronous d-q axis }\end{array}$




\section{INTRODUCTION}

Traditionally, DFIG based wind turbine systems (WTSs) are mainly installed in remote and rural areas [1]. Operation and control of DFIG has been the subject of intense research during last few years. The rotor of the DFIG is connected to AC-DC-AC converter and the stator is connected to the power grid [2]. The principal advantage of the DFIG is that the rotor side converter (RSC) is only sized for $30 \%$ of rated power compared to other generators used in variable speed WTSs. Various control strategies have been proposed for studying the behavior of DFIG-based wind energy conversion systems (WECSs) during normal operation. Indirect vector control [3] and a direct vector control [4] have been proposed for DFIG. In these techniques, the decoupling between q-axis and d-axis current is achieved with feedforward compensation, and thus the DFIG model becomes less difficult and PI controllers can be used [5].

In [6], direct vector control (DTC) was proposed to control DFIG. Similar to the DTC method, a direct power control (DPC) of DFIG based wind energy conversion system has proposed recently [7-9]. In [10], DPC control based on neural network (NNs) has been proposed. In [11], a modified DTC technique was proposed based on second order sliding mode controller (SOSMC) to regulate the electromagnetic torque and rotor flux. In [12], an reactive and active stator power proportional-integral controllers and space vector pulse width modulation (SVPWM) strategy were combined to replace the traditional hysteresis comparators. In [13], a modified DPC strategy was proposed based on SOSMC technique to regulate the reactive and active stator power of the DFIG-based WECS. SOSMC and fuzzy logic (FL) are combined to control the DFIG [14]. In [15], fuzzy sliding mode controller (FSMC) was designed to regulate the active and reactive power of the DFIG-based WTSs.

Neuro-sliding mode controller (NSMC) is proposed to control electromagnetic torque, reactive and active stator power of the DFIG [16]. Artificial neural networks (ANNs) and SOSMC are combined to control the stator reactive and active power of the DFIG [17]. Backstopping control was proposed to control DFIG [18]. In [19], LQR method was designed to control flux and electromagnetic torque of DFIG. In [20], neural space vector pulse width modulation (NSVPWM) and NSMC technique were combined to control DFIG. Fuzzy SVPWM strategy is proposed to reduce the total harmonic distortion (THD) of current and powers ripples of DFIG [21]. In literature [22], vector control (VC) is the most popular technique used in the DFIG based WECS. This control scheme is simple and easy to implement. On the other hand, this strategy gives more THD value of rotor current and powers ripples of DFIG.

To obtain high performance VC, a simple and robust ANFIS-SMC controller is designed to control the RSC and regulate the stator reactive and active stator power. The ANFIS-SMC controller is designed to avoid the reaching phase stability problem. The proposed scheme preserves the advantages of the conventional SMC such as simplicity, less parameters dependence and fast response. In addition, axes transformation of the stator voltage or current is not required. The stability of the ANFIS-SMC controller is proven using lyapunov stability theorem. Finally, the proposed and conventional SMC techniques performance is verified by the simulation study on 1.5 MW DFIG systems under variation parameters, harmonic distortion of stator current and reference tracking.

\section{MATHEMATICAL MODEL OF DFIG}

The general electrical state model of the DFIG obtained using Park transformation is given by (1) $[23,24]$ :

Rotor and stator flux:

$$
\left\{\begin{array}{l}
\psi_{d s}=L_{s} I_{d s}+M I_{d r} \\
\psi_{q s}=L_{s} I_{q s}+M I_{q r} \\
\psi_{d r}=L_{r} I_{d r}+M I_{d s} \\
\psi_{q r}=L_{r} I_{q r}+M I_{q s}
\end{array}\right.
$$

where, $L_{r}$ is the inductance of the rotor, $L_{s}$ is the inductance of the rotor, $M$ is the mutual inductance, $R_{r}$ is the resistances of the rotor windings, $R_{s}$ is the resistances of the stator windings, $\psi_{d r}$ and $\psi_{\mathrm{qr}}$ are the two-phase rotor fluxes, $\psi_{d s}$ and $\psi_{q s}$ are the two-phase stator fluxes.

Rotor and stator voltages: 


$$
\left\{\begin{array}{l}
\mathrm{V}_{\mathrm{ds}}=\mathrm{R}_{\mathrm{s}} \mathrm{I}_{\mathrm{ds}}+\frac{\mathrm{d}}{\mathrm{dt}} \psi_{\mathrm{ds}}-\omega_{\mathrm{s}} \psi_{\mathrm{qs}} \\
\mathrm{V}_{\mathrm{qs}}=\mathrm{R}_{\mathrm{s}} \mathrm{I}_{\mathrm{qs}}+\frac{\mathrm{d}}{\mathrm{dt}} \psi_{\mathrm{qs}}+\omega_{\mathrm{s}} \psi_{\mathrm{ds}} \\
\mathrm{V}_{\mathrm{dr}}=\mathrm{R}_{\mathrm{r}} \mathrm{I}_{\mathrm{dr}}+\frac{\mathrm{d}}{\mathrm{dt}} \psi_{\mathrm{dr}}-\omega_{\mathrm{r}} \psi_{\mathrm{qr}} \\
\mathrm{V}_{\mathrm{qr}}=\mathrm{R}_{\mathrm{r}} \mathrm{I}_{\mathrm{qr}}+\frac{\mathrm{d}}{\mathrm{dt}} \psi_{\mathrm{qr}}+\omega_{\mathrm{r}} \psi_{\mathrm{dr}}
\end{array}\right.
$$

where, $\mathrm{V}_{\mathrm{dr}}$, and $\mathrm{V}_{\mathrm{qr}}$ are the rotor voltages, $\mathrm{V}_{\mathrm{qs}}$ and $\mathrm{V}_{\mathrm{ds}}$ are the two-phase stator voltages, $\mathrm{I}_{\mathrm{dr}}$, and $\mathrm{I}_{\mathrm{qr}}$ are the two-phase rotor currents, $\mathrm{I}_{\mathrm{ds}}$ and $\mathrm{I}_{\mathrm{qs}}$ are the two-phase stator currents.

Reactive and stator active powers:

$$
\left\{\begin{array}{l}
P_{s}=\frac{3}{2}\left(V_{d s} I_{d s}+V_{q s} I_{q s}\right) \\
Q_{s}=\frac{3}{2}\left(V_{q s} I_{d s}-V_{d s} I_{q s}\right)
\end{array}\right.
$$

where, $\mathrm{P}_{\mathrm{s}}$ is the stator active power, $\mathrm{Q}_{\mathrm{s}}$ is the stator reactive power.

Electromagnetic torque is done as:

$$
T_{e}=p M(I d r . I q s-I q r . I d s)
$$

where, $\mathrm{T}_{\mathrm{e}}$ is the electromagnetic torque, $p$ is the number of pole pairs.

And its associated motion equation is:

$$
T_{e}=T_{r}+J \cdot \frac{d \Omega}{d t}+f \cdot \Omega
$$

where, $T_{r}$ is the load torque, $\Omega$ is the mechanical rotor speed, $\mathrm{J}$ is the inertia, $f$ is the viscous friction coefficient.

\section{SVPWM TECHNIQUE}

Space vector modulation strategy is widely used in variable speed drive of AC machine. This technique gives $15 \%$ more voltage output compare to conventional pulse width modulation (PWM). On the other hand, this strategy minimizes the THD of voltage and powers ripples this technique based on the principal of space vectors and need to calculate of angle and zone [25]. This strategy is detailed in [26]. However, this method of modulation is difficult to implement compared to PWM strategy. To avoid the disadvantages of the SMC technique, a new SVPWM scheme has been discussed in this paper [27]. This proposed strategy based on calculation of maximum (Max) and minimum (Min) of three-phase voltages [28].

The advantages of the proposed SVPWM strategy is not needed to calculate the zone and angle, simple scheme and easy to implement compared to classical SVPWM method. This proposed technique is detailed in [29]. The proposed SVPWM algorithm, which is designed to control the two-level inverter, is shown in Figure 1. 


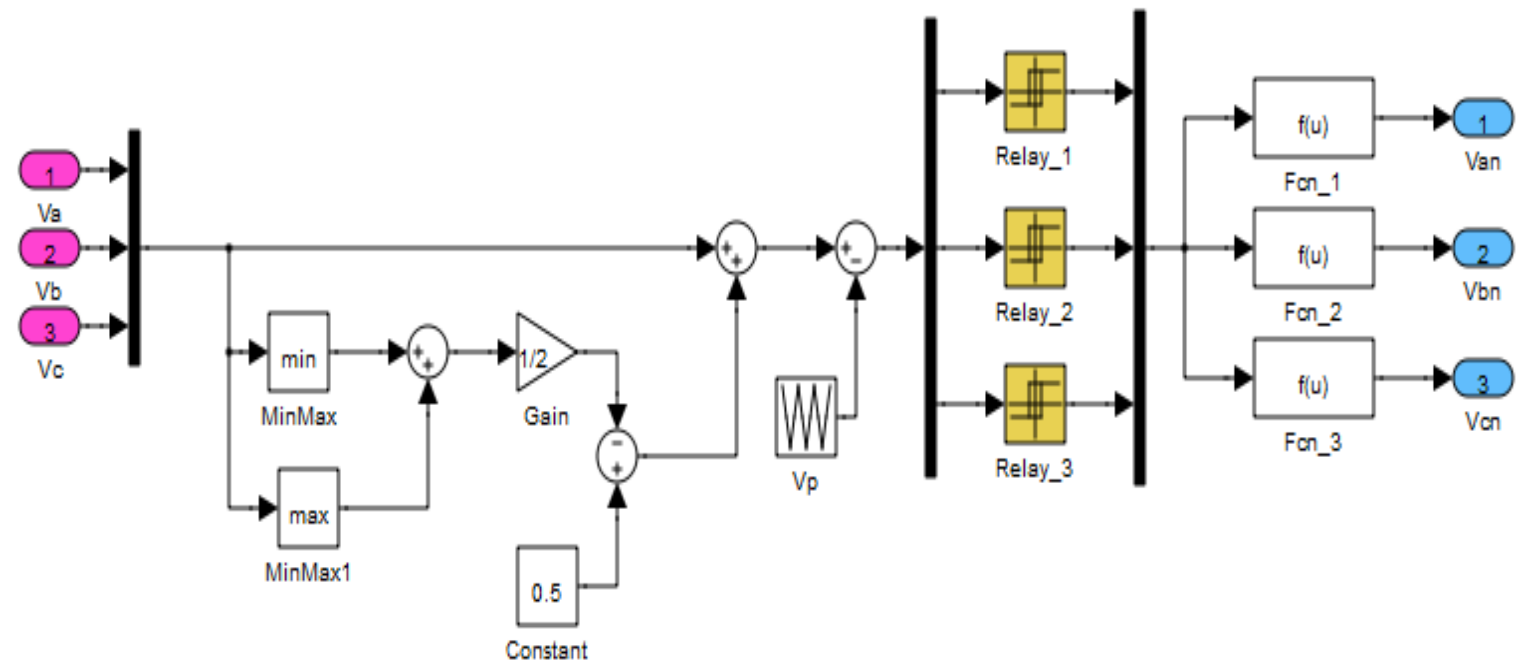

Figure 1. Simulation block of proposed SVPWM technique

\section{ANFIS-SMC CONTROL}

In control system, SMC control is a type of variable structure control (VSV). It is a nonlinear control technique. The SMC method was proposed by Utkin in 1977 [30]. However, this technique is simple control scheme and easy to implement compared to traditional control techniques. Since the robustness is the best advantage of an SMC strategy [31]. But, this strategy has an essential disadvantage, which is the chattering phenomenon caused by the discontinuous control action [32]. This strategy gives more distortion harmonic of rotor voltage, electromagnetic torque ripple and powers ripples.

In order to improve the conventional SMC, a complimentary use of adaptive neuro-fuzzy inference system (ANFIS) controller is proposed. The ANFIS controller has been used in many application and this method is simple scheme and easy to implement. This strategy was proposed by Jang in 1995 [33]. This strategy based on observation and engineering experience. In ANFIS control, does not need a mathematical model of system [34]. On the other hand, the ANFIS controller structure consiste of four blocks that are defuzzification, fuzzification, knowledge base and neural network. One way to improve SMC technique performance is to combine it with ANFIS to form a ANFIS-SMC. The design of a sliding mode controller incorporating ANFIS control helps in achieving reduced chattering, simple control scheme, reduced harmonic distortion of voltage and robustness against disturbances and nonlinearities.

\subsection{Sliding mode controller}

The SMC technique goes through three stages, as follows:

a) Choice of switching surface

b) Convergence condition

c) Control calculation.

The sliding mode reactive and active stator powers controllers are designed to respectively change the $d$ and $q$-axis voltages $\left(V_{q r}^{*}\right.$ and $V_{d r}^{*}$ ) as in (6) [27].

$$
\left\{\begin{array}{l}
V_{d r}^{e q}=R_{r} \cdot I_{d r}-L_{s} \frac{\left(L_{r}-\frac{M^{2}}{L_{s}}\right)}{M \psi_{s} w_{s}} \dot{Q}_{s_{r e f}}-g \cdot w_{s} \cdot\left(L_{r}-\frac{M^{2}}{L_{s}}\right) \cdot I_{q r}+\frac{\left(L_{r}-\frac{M^{2}}{L_{s}}\right)}{M} w_{s} \\
V_{q r}^{e q}=R_{r} \cdot I_{q r}+\frac{L_{s}}{V_{s} M} \dot{P}_{s_{r e f}}-g \cdot w_{s} \cdot\left(L_{r}-\frac{M^{2}}{L_{s}}\right) \cdot I_{d r}+g \cdot \frac{M \cdot V_{s}}{L_{s}}
\end{array}\right.
$$

To obtain good performances, dynamic and a commutation around the surface, the command vector is imposed as follows [35]:

$$
V_{d q}=V_{d q}^{e q}+V_{d q}^{n}
$$


$V_{d q}^{n}$ is the saturation function defined by:

$V_{d q}^{n}=-K . \operatorname{sat}\left(S_{d q}\right)$

where $K$ determine the ability of overcoming the chattering.

The SM will exist only if the following condition is met:

$$
S . S \prec 0
$$

Conventional SMC technique as shown in Figure 2.

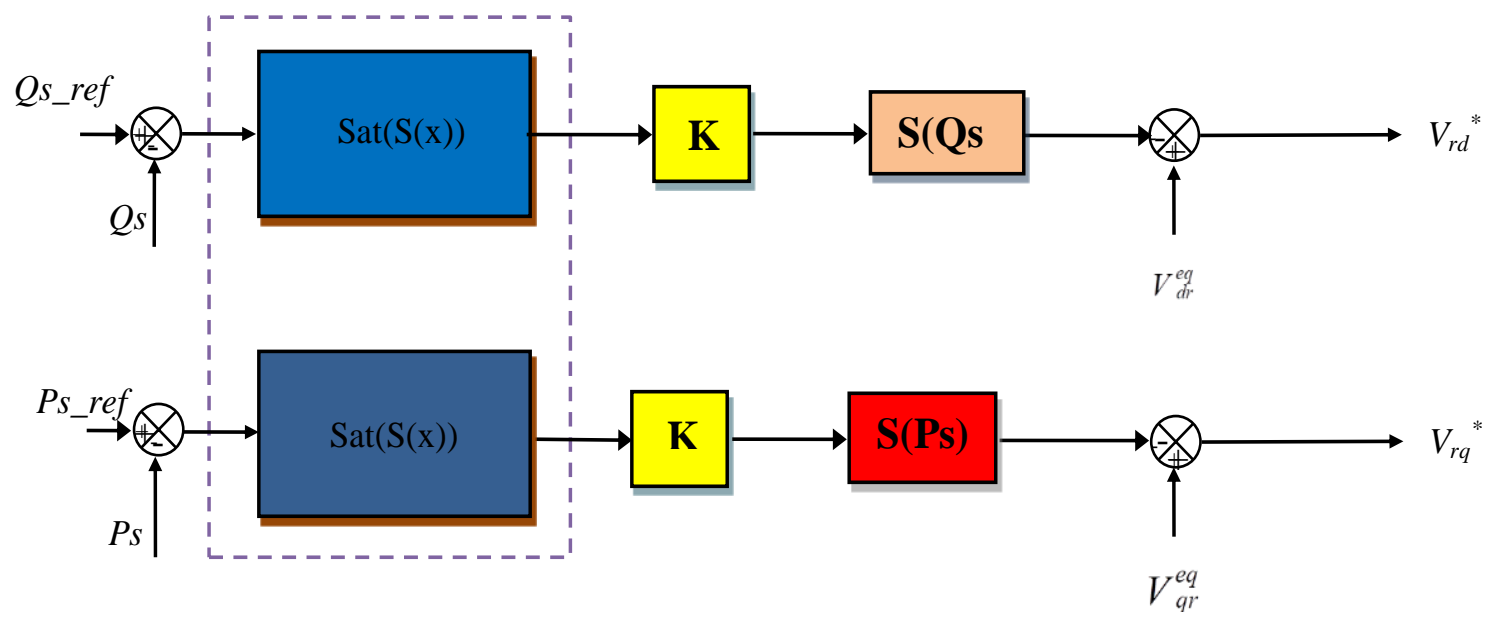

Figure 2. Conventional SMC technique

\subsection{Anfis-sliding mode controller}

The ANFIS-SMC goal is to control the reactive and active stator powers of the DFIG-based WTS. The ANFIS-SMC is similar to a conventional SMC strategy. However, the switching regulators term sat $(\mathrm{S}(\mathrm{x}))$, has been replaced by ANFIS controller as given by Figure 3. On the other hand, the ANFIS-SMC control gives more and more minimum THD value of rotor current compared to classical SMC method. Fuzzy system has 49 roles. This roles for the proposed system are given in Table 1 [23]. The membership function definition is shown in Figure 4. We use the next designations for membership functions:

NB: Negative Big

NM: Negative Middle

NS: Negative Small

PS: Positive Small

PB: Positive Big

EZ: Equal Zero

PM: Positive Middle.

Table 1. Fuzzy logic rols

\begin{tabular}{clllllll}
\hline $\begin{array}{c}\mathrm{e} \\
\mathrm{e}\end{array}$ & $\mathrm{NB}$ & $\mathrm{NM}$ & $\mathrm{NS}$ & EZ & PS & PM & PB \\
\hline NB & NB & NB & NB & NB & NM & NS & EZ \\
NM & NB & NB & NB & NM & NS & EZ & PS \\
NS & NB & NB & NM & NS & EZ & PS & PM \\
EZ & NB & NM & NS & EZ & PS & PM & PB \\
PS & NM & NS & EZ & PS & PM & PB & PB \\
PM & NS & EZ & PS & PM & PB & PB & PB \\
PB & EZ & PS & PM & PB & PB & PB & PB \\
\hline
\end{tabular}




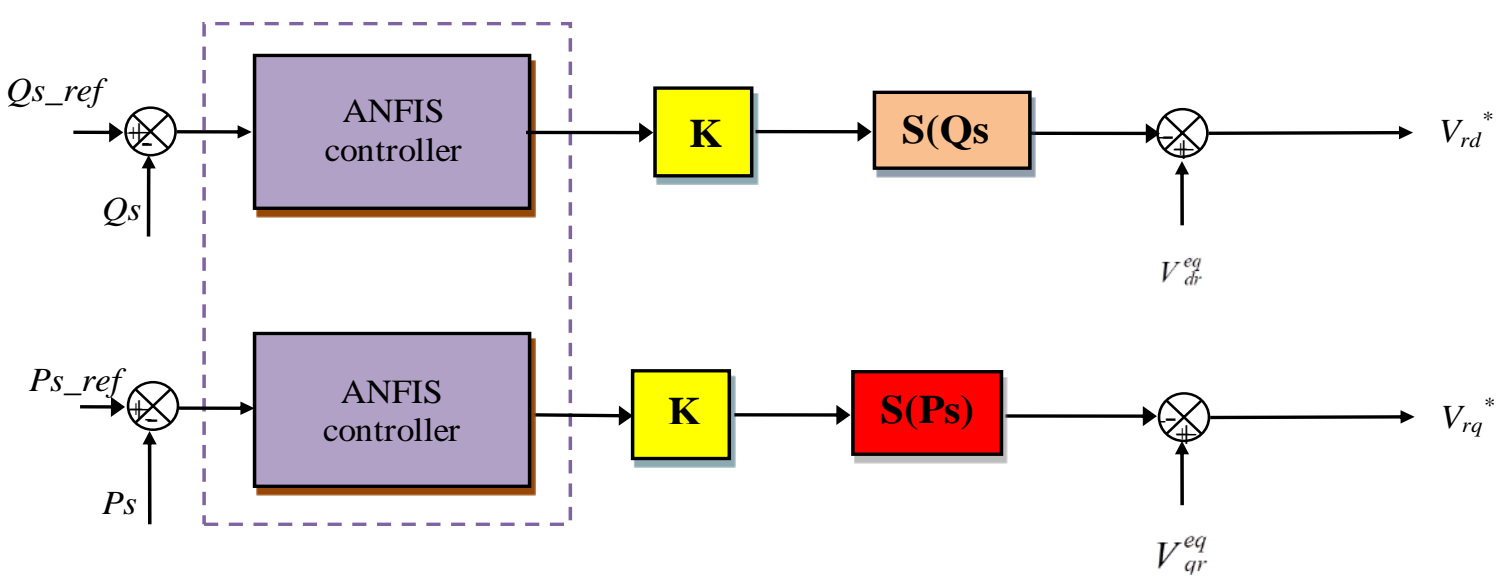

Figure 3. ANFIS-SMC technique
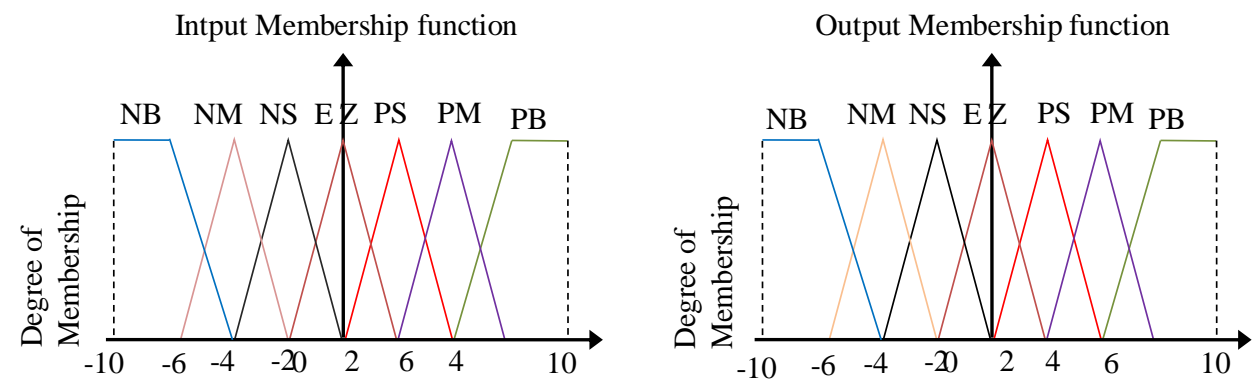

Figure 4. FL sets and its memberships functions

The training used is that of the algorithm, Gradiant descent with momentum \& Adaptive LR. The convergence of the network in summer obtained by using the value of the parameters grouped in Table 2. For the two proposed ANFIS-sliding mode controllers in Figure 3, the structure of the ANFIS controller is shown in Figure 5. The proposed ANFIS-SMC with SVPWM strategy, which is designed to control reactive stator power and active power of the DFIG-based WTS, is shown in Figure 6.

Table 2. Parameters of the LR

\begin{tabular}{lc}
\hline Parameters of the LM & Values \\
\hline Number of hidden layer & 12 \\
TrainParam.Lr & 0.002 \\
TrainParam.show & 50 \\
TrainParam.eposh & 1000 \\
Coeff of acceleration of convergence (mc) & 0.9 \\
TrainParam.goal & 0 \\
TrainParam.mu & 0.9 \\
Functions of activation & Tensing, Purling, gensim
\end{tabular}

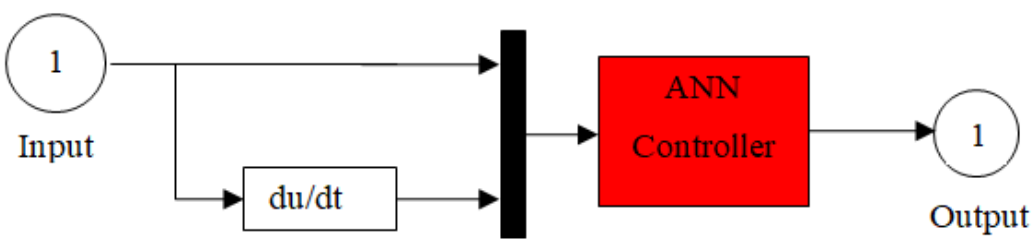

Figure 5. Architecture of ANFIS controller 


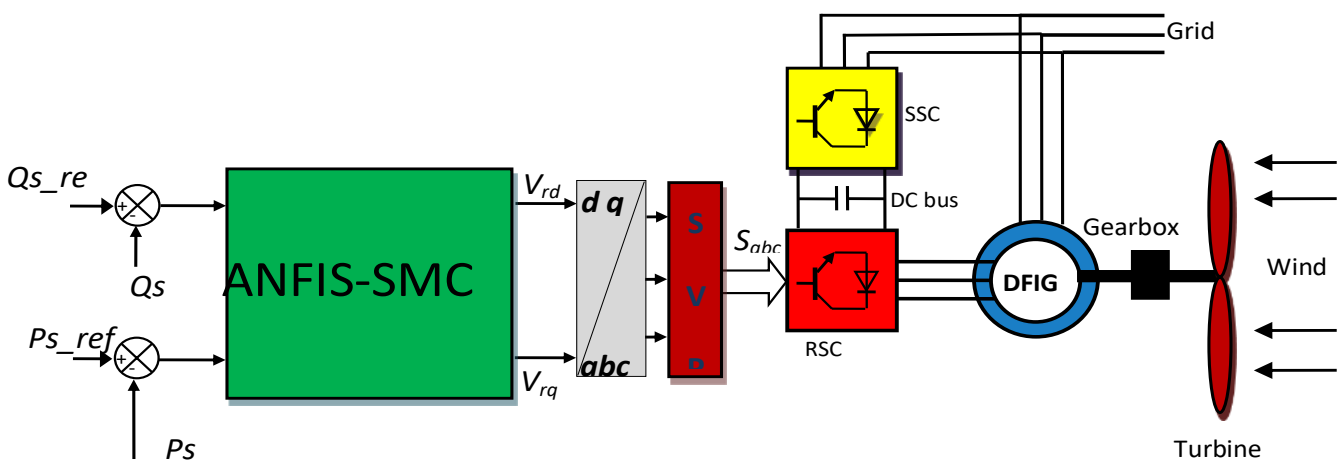

Figure 6. Block diagram of the ANFIS-SMC with SVPWM technique

\section{RESULTS}

The ANFIS-SMC control of a DFIG-based WTS is implemented with simulation tools of MATLAB/Simulink. The DFIG attached to a 398 V/50 Hz grid. Both control techniques ANFIS-SMC using SVPWM and conventional SMC using SVPWM technique are simulated and compared regarding reference tracking, rotor current harmonics distortion, and robustness against doubly fed induction generator parameter variations. The DFIG used in this case study is a $1.5 \mathrm{MW}, 380 / 696 \mathrm{~V}$, two poles, $50 \mathrm{~Hz}$; with the following parameters: $\mathrm{Rs}=0.012 \Omega, \mathrm{Rr}=0.021 \Omega, \mathrm{Ls}=0.0137 \mathrm{H}, \mathrm{Lr}=0.0136 \mathrm{H}$ and $\mathrm{Lm}=0.0135 \mathrm{H}$. The system has the following mechanical parameters: $\mathrm{J}=1000 \mathrm{~kg} . \mathrm{m} 2$, fr $=0.0024 \mathrm{Nm} / \mathrm{s}$.

\subsection{Reference tracking test (RTT)}

Figures 7 and 8 shows the THD of rotor current of the DFIG-based WTS obtained using FFT (Fast Fourier Transform) method for ANFIS-SMC control with SVM (ANFIS-SMC-SVPWM) and conventional SMC with SVPWM one respectively. It can be clearly observed that the THD is minimized for ANFIS-SMC control when compared to conventional SMC with SVPWM technique. Table 3 shows the comparative analysis of THD value.
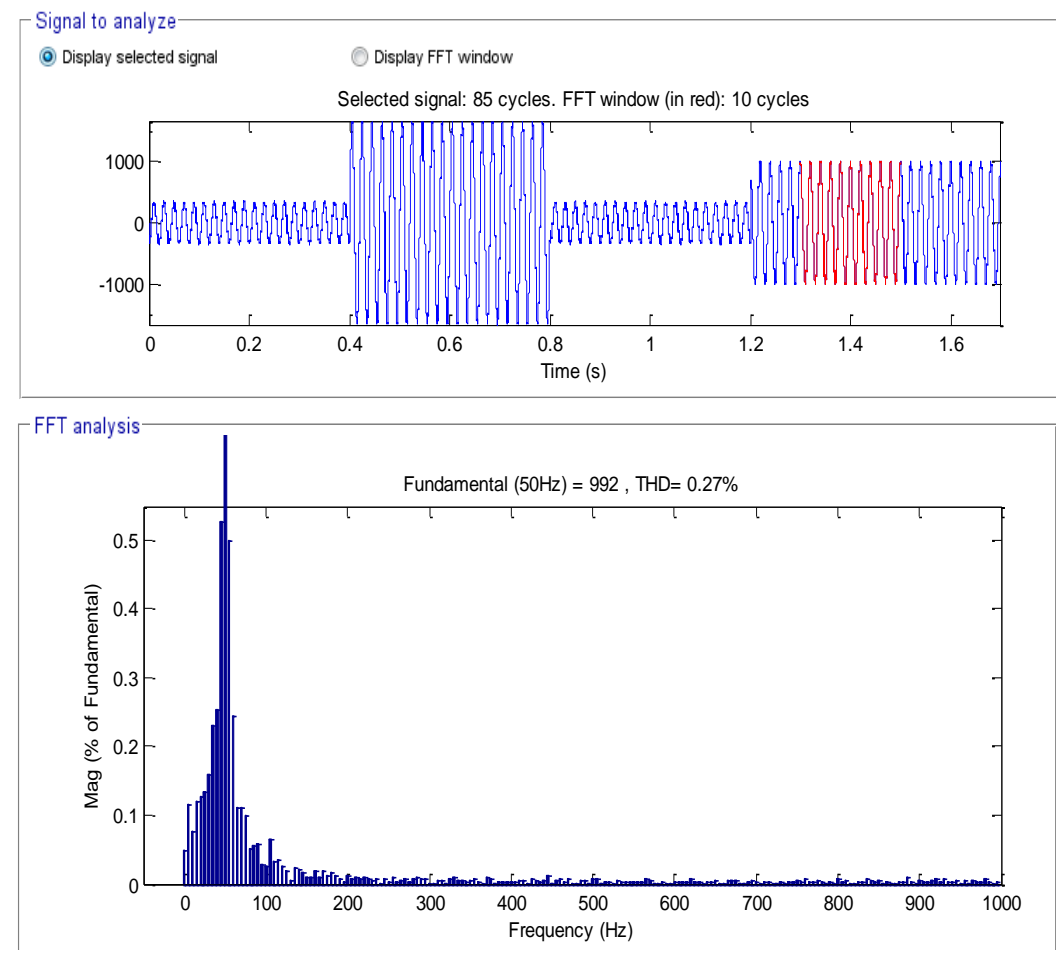

Figure 7. Spectrum harmonic of rotor current (SMC) 

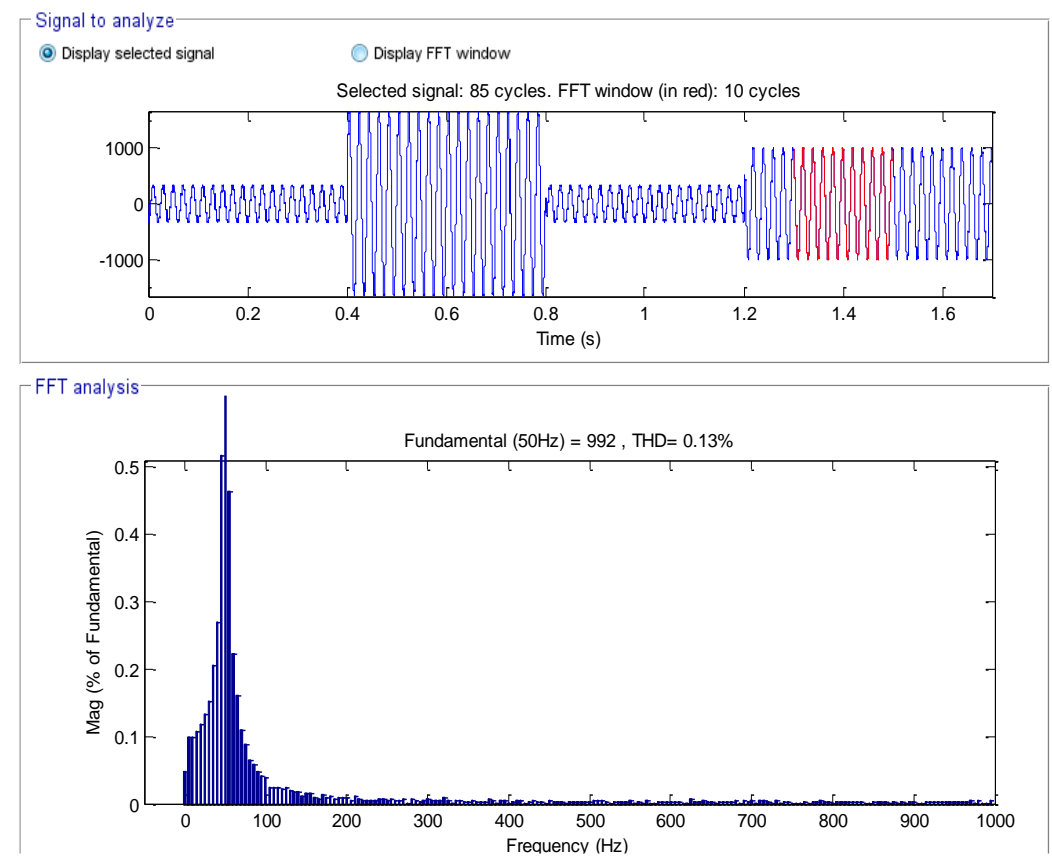

Figure 8. Spectrum harmonic of rotor current (ANFIS-SMC)

Table 3. Comparative analysis of THD value (RTT)

\begin{tabular}{ccc}
\hline & \multicolumn{2}{c}{ THD (\%) } \\
\cline { 2 - 3 } Rotor current & SMC & ANFIS-SMC \\
& 0.27 & 0.13 \\
\hline
\end{tabular}

For the ANFIS-SMC and SMC control scheme, the active stator power (Ps) and reactive stator power (Qs) tracks almost perfectly their references values $\left(\mathrm{Ps}_{\text {ref }}\right.$ and $\left.\mathrm{Qs}_{\text {ref }}\right)$, see Figures 9 and 10. Figure 11 shows the electromagnetic torque of the both strategies. The simulation result validates the torque ripple is reduced in the proposed control scheme based DFIG drive (See Figure 14).On the other hand, the ANFISSMC control scheme using the two-level SVPWM strategy minimized the reactive stator power ripples, electromagnetic ripples and active stator power ripples compared to the traditional SMC using two-level SVPWM technique, see Figures 12-14.

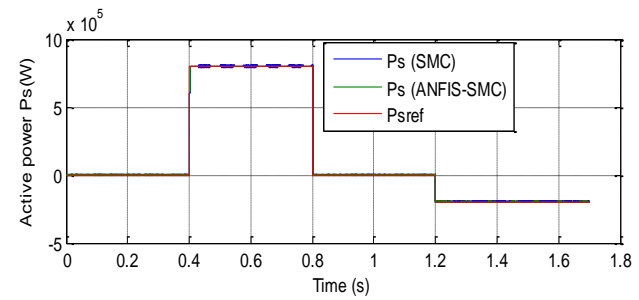

Figure 9. Active stator power (RTT)

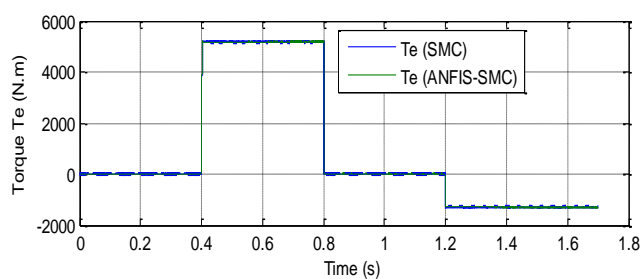

Figure 11. Electromagnetic torque (RTT)

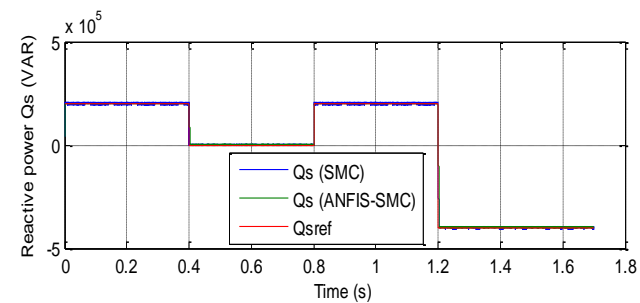

Figure 10. Reactive stator power (RTT)

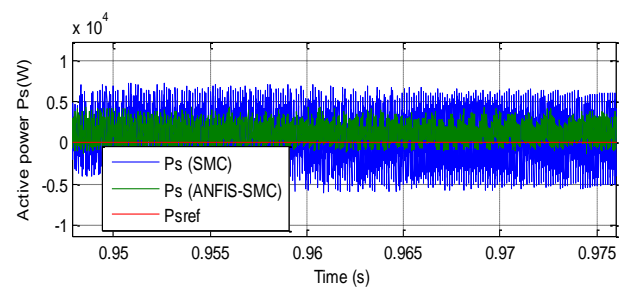

Figure 12. Zoom in the active stator power (RTT) 


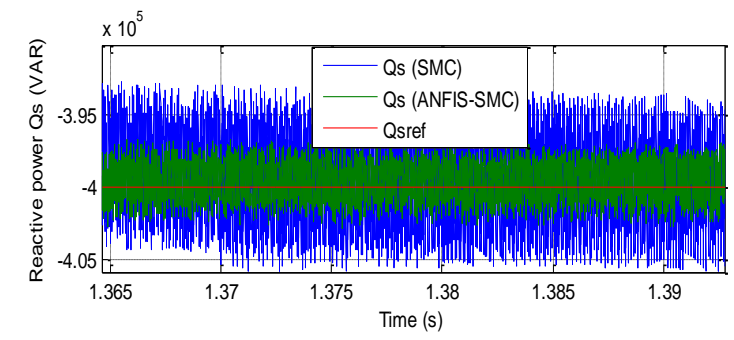

Figure 13. Zoom in the reactive stator power (RTT)

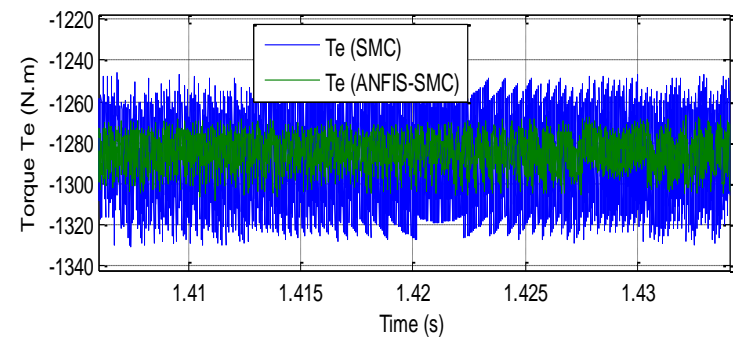

Figure 14. Zoom in the torque (RTT)

\subsection{Robustness test (RT)}

In this section, the nominal value of the $R_{r}$ and $R_{s}$ is multiplied by 2 , the values of inductances $L_{s}, M$, and $L_{r}$ are multiplied by 0.5. Simulation results are presented in Figures 15-19. As it's shown by these figures, these variations present an apparent effect on the active stator power, reactive stator power and electromagnetic torque curves and that the effect appears more significant for the SMC control with SVPWM strategy compared to ANFIS-SMC control with SVPWM, see Figures 20-22. The THD value of rotor current in the ANFIS-SMC control scheme has been minimized significantly, see Figures 15-16. Table 4 shows the comparative analysis of THD value. Thus it can be concluded that the proposed ANFIS-SMC control with SVPWM strategy is more robust than the conventional SMC with SVPWM strategy.
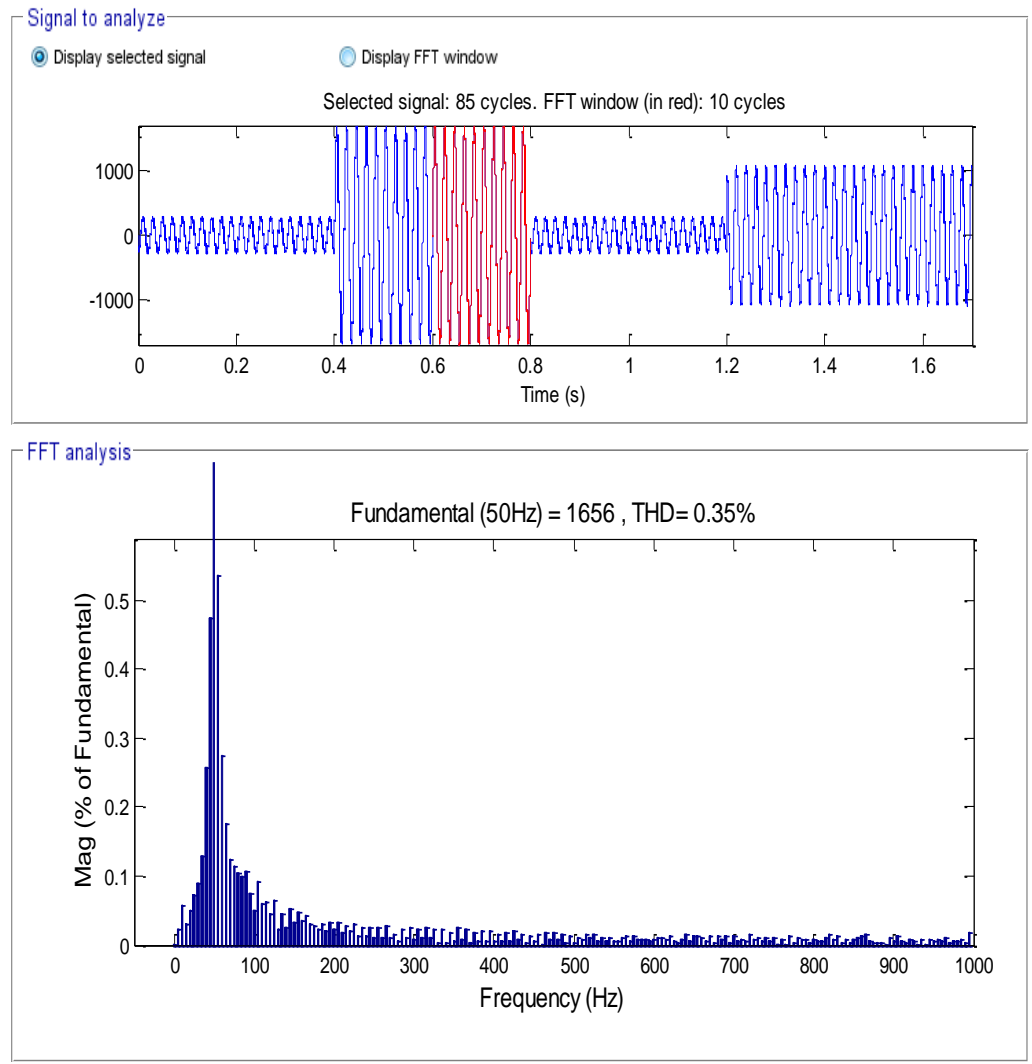

Figure 15. Spectrum harmonic of rotor current (SMC)

Table 4. Comparative analysis of THD value (RT)

\begin{tabular}{ccc}
\hline & \multicolumn{2}{c}{ THD (\%) } \\
\cline { 2 - 3 } & SMC & ANFIS-SMC \\
Rotor current & 0.35 & 0.18 \\
\hline
\end{tabular}




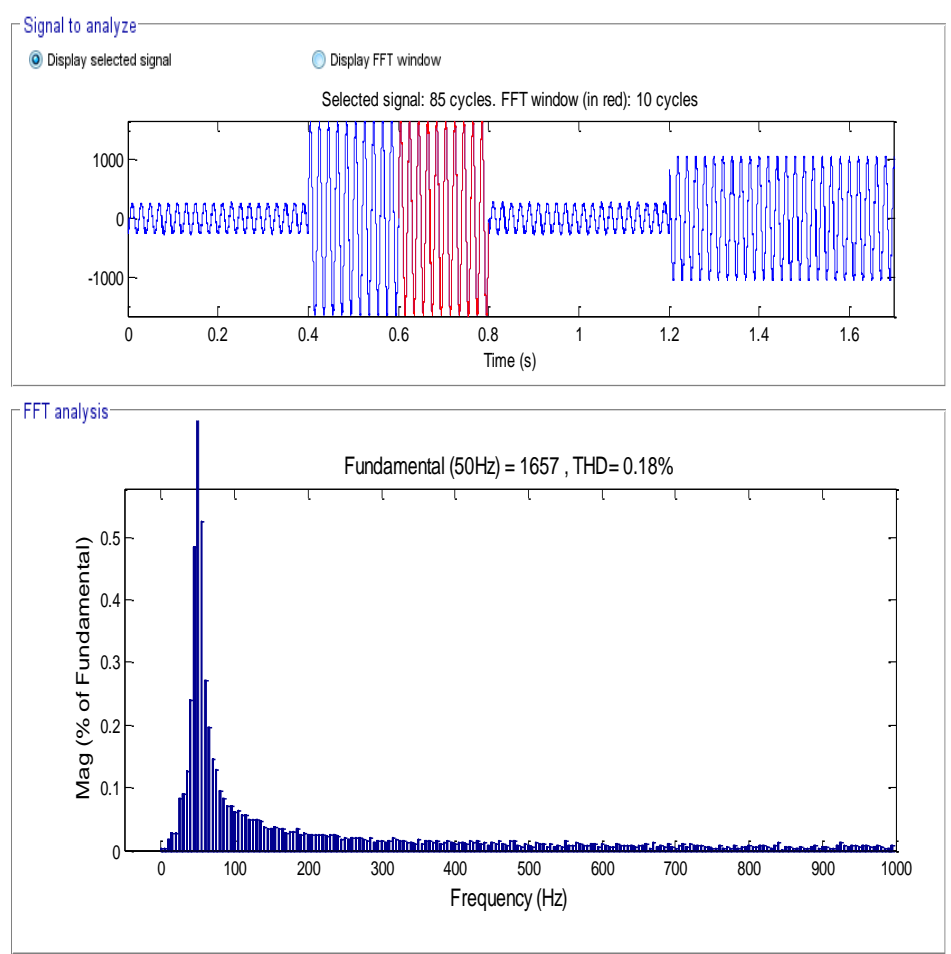

Figure 16. Spectrum harmonic of rotor current (ANFIS-SMC)

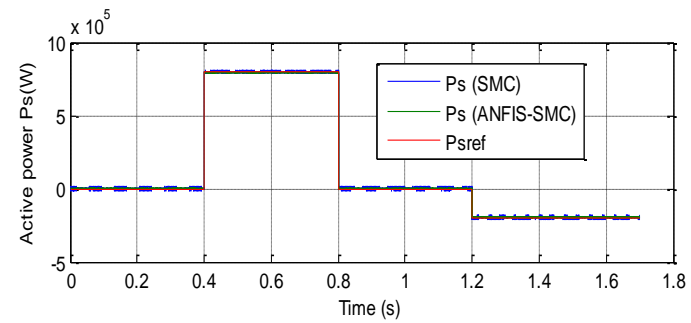

Figure 17. Active stator power (RT)

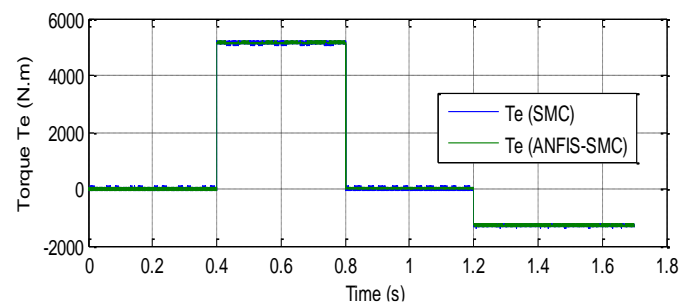

Figure 19. Electromagnetic torque (RT)

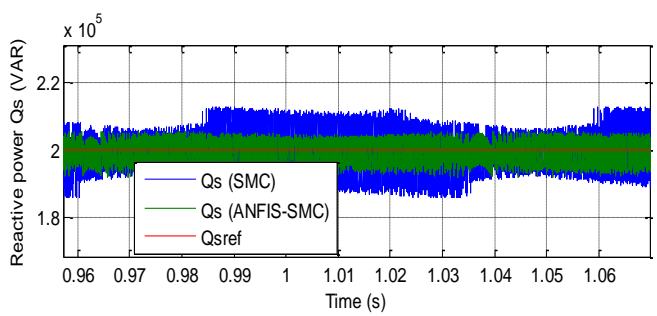

Figure 21. Zoom in the reactive stator power (RT)

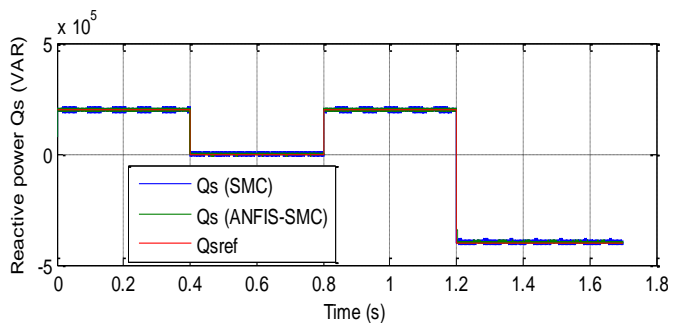

Figure 18. Reactive stator power (RT)

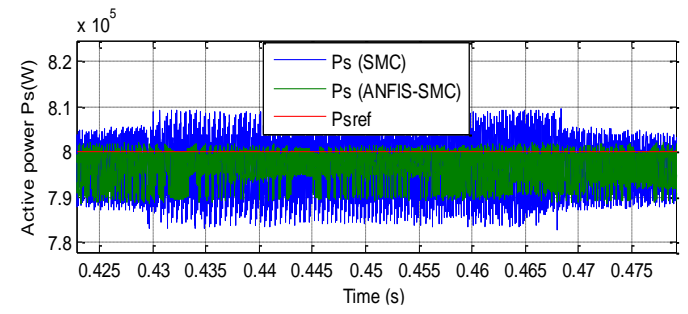

Figure 20. Zoom in the active stator power (RT)

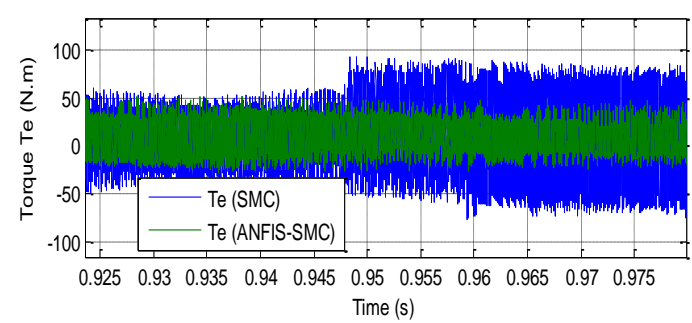

Figure 22. Zoom in the torque (RT) 


\section{CONCLUSION}

In this paper, the ANFIS-SMC principle is presented and it is shown that with SVPWM technique for a two-level inverter. The simulation results obtained for the ANFIS-SMC with SVPWM technique illustrate a considerable reduction in reactive power ripple, active stator power ripple, electromagnetic torque ripple and THD value of rotor current compared to the conventional SMC utilizing two-level SVPWM strategy.

\section{REFERENCES}

[1] A. Fayssal, A. Chaiba, B. Babes and S. Mekhilef, "Design and implementation of high performance field oriented control for grid-connected doubly fed induction generator via hysteresis rotor current controller," Rev. Roum. Sci. Techn.-Electrotechn. Et Energ, vol. 61, no. 4, pp. 319-324, 2016.

[2] Yuan-Kang Wu and Wu-Han Yang, "Different control strategies on the rotor side converter in DFIG-based wind turbines," Energy Procedia,vol. 100, pp. 551-555, 2016.

[3] A. Medjber, A. Moualdia and A. Mellit et M. A. Guessoum, "Comparative study between direct and indirect vector control applied to a wind turbine equipped with a double-fed asynchronous machine article," International Journal of Renewable Energy Research, vol. 3, no. 1, pp. 88-93, 2013.

[4] H. Benbouhenni, Z. Boudjema and A. Belaidi, "Direct vector control of a DFIG supplied by an intelligent SVM inverter for wind turbine system", Iranian Journal of Electrical \& Electronic Engineering, vol. 15, no. 1, pp. 45-55, 2019.

[5] K. Kerrouchem, A. Mezouar and Kh. Belgacem, "Decoupled control of doubly fed induction generator by vector control for wind energy conversion system," Energy Procedia, vol. 42, pp. 239-248, 2013.

[6] Y. S. Rao and A. J. Laxmi, "Direct torque control of doubly fed induction generator based wind turbine under voltage dips," International Journal of Advances in Engineering \& Technology, vol. 3, pp. 711-720, 2012.

[7] S. Massoum, A. Meroufel, A. Massoum and P. Wira, "A direct power control of the doubly-fed induction generator based on the SVM strategy,” Elektrotehniski Vestnik, vol. 84, no. 5, pp. 235-240, 2017.

[8] S. M. Tavakoli, M. A. Pourmina and M. R. Zolghadri, "Comparison between different DPC methods applied to DFIG wind turbines," International Journal of Renewable Energy Research, vol. 3, no. 2, pp. 446-452, 2013.

[9] A. Izanlo, S. A. Gholamian and M. V. Kazemi, "Comparative study between two sensorless methods for direct power control of doubly fed induction generator," Rev. Roum. Sci. Techn.-Electrotechn. Et Energ, vol. 62, no. 4, pp. 358-364, 2017.

[10] A. Bakouri, H. Mahmoudi and A. Abbou, "Intelligent control for doubly fed induction generator connected to the electrical network,"International Journal of Power Electronics and Drive System, vol. 7, no. 3, pp. 688-700, 2016.

[11] Z. Boudjema, R. Taleb, Y. Djeriri, A. Yahdou, "A novel direct torque control using second order continuous sliding mode of a doubly fed induction generator for a wind energy conversion system," Turkish Journal of Electrical Engineering \& Computer Sciences, vol. 25, pp. 965-975, 2017.

[12] S. Jou, S. Lee, Y. Park and K. Lee, "Direct power control of a DFIG in wind turbines to improve dynamic responses,” J. Power Electron. vol. 9, no. 5, pp. 781-790, 2009.

[13] A. Bouyekni, R. Taleb, Z. Boudjema and H. Kahal, "A second-order continuous sliding mode based on DPC for wind-turbine-driven DFIG,” Elektrotehniški Vestnik, vol. 85, no.1-2, pp. 29-36, 2018.

[14] H. Benbouhenni, "Fuzzy second order sliding mode controller based on three-level fuzzy space vector modulation of a DFIG for wind energy conversion systems," Majlesi Journal of Mechatronic Systems, vol. 7, no. 3, 2018.

[15] S. E. Ardjoun and M. Abid, "Fuzzy sliding mode control applied to a doubly fed induction generator for wind turbines," Turkish Journal of Electrical Engineering \& Computer Sciences, vol. 23, pp. 1673-1686, 2015.

[16] H. Benbouhenni, "Comparison study between FPWM and NSVM inverter in neuro-sliding mode control of reactive and active power control of a DFIG-based wind energy," Majlesi Journal of Energy Management, vol. 6, no. 4, 2017.

[17] H. Benbouhenni, Z. Boudjema and A. Belaidi, "Neuro-second order sliding mode control of a DFIG supplied by a two-level NSVM inverter for wind turbine system," Iranian Journal of Electrical \& Electronic Engineering, vol.14, no. 3, pp. 362-373, 2018.

[18] M. El-Azzaoui, Mahmoudi H. and K. Boudaria, "Backstepping control of wind and photovoltaic hybrid renewable energy system," Internationale Journal of Power Electronics and Drive Systems, vol. 7, no. 3, pp. 677-686, 2016.

[19] A. Khajah and R. Ghazi, "GA-based optimal LQR controller to improve LVRT capability of DFIG wind turbine," Iranian Journal of Electrical \& Electronic Engineering, vol. 9, no. 3, pp. 167-176, 2013.

[20] H. Benbouhenni, A. Moussaoui and Z. Boudjema, "Wind energy conversion systems based on a DFIG controlled by neuro-sliding mode control using NSVM and PWM," International Conference on Electrical Engineering, pp. 17-18, December 2018.

[21] H. Benbouhenni, Z. Boudjema and A. Belaidi, " Using three-level Fuzzy space vector modulation method to improve indirect vector control strategy of a DFIG based wind energy conversion systems," International Journal of Smart Grid, vol. 2, no. 3, pp.155-171, 2018.

[22] F. Amrane and A. Chaiba, "A novel direct power control for grid-connected doubly fed induction generator based on hybrid artificial intelligent control with space vector modulation," Rev. Roum. Sci. Techn.-Electrotechn. Et Energ, vol. 61, no. 3, pp. 263-268, 2016. 
[23] A. Chemidi, S. M. Meliani and M. C. Benhabib "Performance analysis of DFIG wind power system fed by matrix converter, "Electrotehnica Electronica Automatica (EEA), vol. 63, no. 1, pp. 78-87, 2015.

[24] B. Belabbas, T. Allaloui, M. Tadjine, M. Denai, "High order sliding mode controller simulation by a wind turbine for DFIG protection against overcurrent," Electrotehnica Electronica Automatica (EEA), vol. 65, no. 4, pp. 142-147, 2017.

[25] H. Benbouhenni, Z. Boudjema and A. Belaidi, "DFIG-based wind turbine system using four-level FSVM strategy," Majlesi Journal of Energy Management, vol. 6, no. 3, 2017.

[26] H. Benbouhenni, Z. Boudjema and A. Belaidi, " DFIG-based wind turbine system using three-level neural space vector modulation technique," Majlesi Journal of Mechatronic Systems, vol. 7, no. 2, pp. 35-45, 2018.

[27] H. Benbouhenni, "Comparison study between FPWM and NSVM inverter in neuro-sliding mode control of reactive and active power control of a DFIG-based wind energy," Majlesi Journal of Energy Management, vol. 6, no. 4, pp. 15-23 2017.

[28] H. Benbouhenni, Z. Boudjema and A. Belaidi, "A comparative study between four-level NSVM and three-level NSVM technique for a DFIG-based WECSs controlled by indirect vector control," Carpathian Journal of Electronic and Computer Engineering, vol. 11, no. 2, pp.13-19, 2018.

[29] H. Benbouhenni, " Neuro-sconde order sliding mode field oriented control for DFIG based wind turbine, » International Journal Of Smart Grid, vol. 2, no. 4, pp. 209-217, 2018.

[30] Y. Bekakra and D. Ben Attous, "Comparison study between SVM and PWM inverter in sliding mode control of active and reactive power control of a DFIG for variable speed wind energy," International Journal of Renewable Energy Research, vol. 2, no. 3, pp. 471-476, 2012.

[31] Z. Boudjema, A. Meroufel and A. Amari, "Robust control of a doubly fed induction generator (DFIG) fed by a direct AC-AC converter," Przeglad Elektrotechniczny, vol. 11, pp. 213-221, 2012.

[32] Z. Boudjema, R. Taleb and A. Yahdou, "A new DTC scheme using second order sliding mode and fuzzy logic of a DFIG for wind turbine system," International Journal of Advanced Computer Science and Applications, vol. 7, no. 8, pp. 49-56, 2016.

[33] T. Wang, C. Sabourin and K. Madani, “ANFIS controller for non-holonomic robots," Majlesi Journal of Electrical Engineering, vol. 5, no. 2, pp. 31-37, 2011.

[34] A. K. Pouya, "Design of adaptive neural fuzzy controller for speed control of BLDC motors," Majlesi Journal of Electrical Engineering, vol. 11, no. 1, pp. 37-43, 2017.

[35] A. M Fihakhir and M. Bouhamida, "Nonlinear Control of a Doubly Fed Induction Generator Driven Wind Turbine," Electrotehnica Electronica Automatica (EEA), vol. 64, no. 2, pp. 23-30, 2016.

\section{BIOGRAPHY OF AUTHOR}

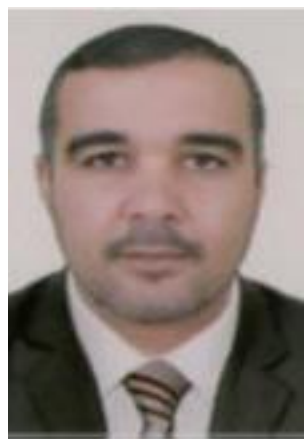

H. Benbouhenni was born in chlef, Algeria. He is a PhD student in the Departement of electrical engineering at the ENPO-MA, Oran, Algeria. He received a M.A. degree in Automatic and informatique industrial in 2017. His research activities include the application of robust control in the wind turbine power systems.

E-mail: habib0264@gmail.com ; habib_benbouhenni@yahoo.com 